\title{
AN ECONOMIC STUDY OF THE USE OF INSECTICIDES FOR THE CONTROL OF PORINA CATERPILLAR
}

\author{
G. F. McLaren \\ Field Research Officer, Alexandra. \\ D. K. CRUMP \\ Farm Advisory Officer (Economics), Dunedin \\ Summary
}

Results were obtained from a number of experiments where pasture yields had been measured from insecticide-treated and non-treated areas. A relationship was found between porina numbers in the autumn and the $\%$ pasture lost. This was used to find the economic threshold levels for insecticide use under varying conditions of insecticide costs, stocking rates and gross margin per ewe equivalent.

THE economic importance of porina caterpillar (Wiseana cervinata) as a pasture pest has been recognized for a number of years but it is only since the teplacement of DDT by organophosphate insecticides that farmers have had to consider seriously the cost of insecticide treatment. The presence of porina infestations results in reduced net income to the farmer, claused either by a loss of production from untreated pastures, or the cost of treatment where insecticides are used. Consequently, the farmer is faced with the problem of how to minimize costs when considering this, or any other pasture pest.

The reduction in income caused by porina and grass grub (Costelytra zealandica) infestations on a Canterbury mixed cropping farm was studied by Flay and Garrett (1942). Grass grub was used as an example of a pasture pest which exhibits an infestation cycle, in a theoretical study of insect control carried out by Jensen (1967). He described a method of economic analysis that could be used when more information became available on the losses caused by pasture pests. Rastrick and Upritchard (1968) illustrated that it was economic to treat a heavily infested area, while Allen (1968) showed that a porina population of one per square foot consumed sufficient pasture to support 0.17 ewe equivalent per acre during the eight-week period he was studying.

PART I: BIOLOGICAL ASPECTS

Methods

Two trial sites were established in Central Otago during 1966. Insecticides were used to give a comparison of yields from porina-infested and uninfested areas. The trials were not stocked, but were mown several times during each growing season and the pasture production calculated in terms of pounds dry matter per acre. Porina numbers were recorded at different times of the year. 


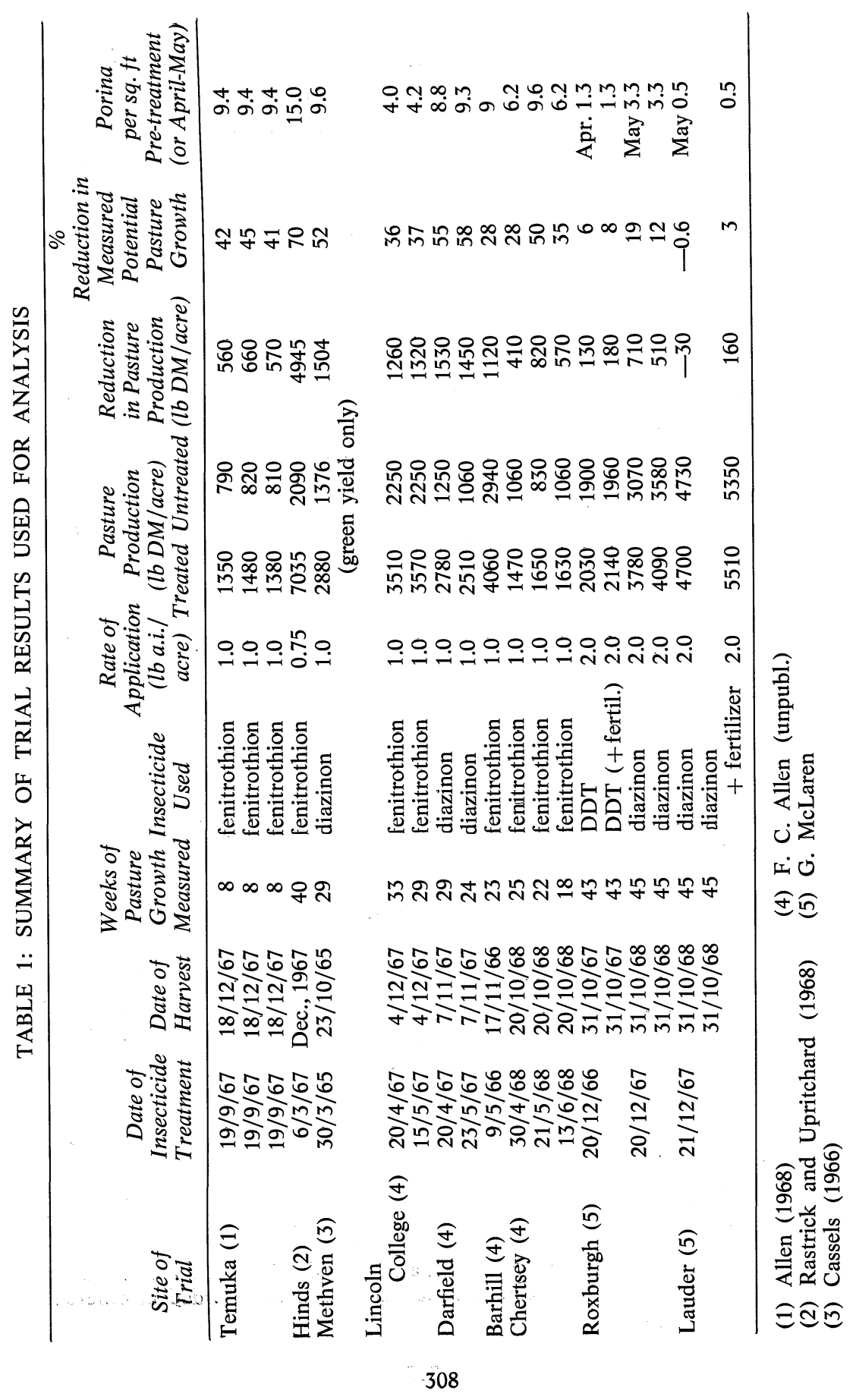


In addition, experimental results were collected from published and unpublished sources. In these experiments, insecticides had been used to control porina, pasture vields had been measured, and porina numbers counted at the time of treatment.

The proportion $(\%)$ of potential pasture production which had been lost through the activity of porina was compared with porina numbers present prior to insecticide treatment. This meant that, in most cases, positive damage which occurred over the following six months (April to October) was compared with the porina numbers found in March, April or May.

The method of economic analysis used, together with the results and discussion arising from it, will be discussed in Part II. Part I will be concerned mainly with the biological aspects of the study.

\section{Results}

The results obtained are presented in Table 1, together with details of trial locality, time of treatment, insecticides and the rates of application used. A correlation which was found between the percentage reduction in potential pasture yield and porina population levels is presented graphically in Fig. $1(r=0.92)$. This correlation is the basis of the economic analysis presented in Part II.

\section{Discussion}

Relationship between \% Reduction in Potential Pasture Production and Porina Numbers

Considering the variety of sites and seasons from which the original results have been drawn, as well as differences in research techniques, times of year and time spans considered, it would appear that the relation-

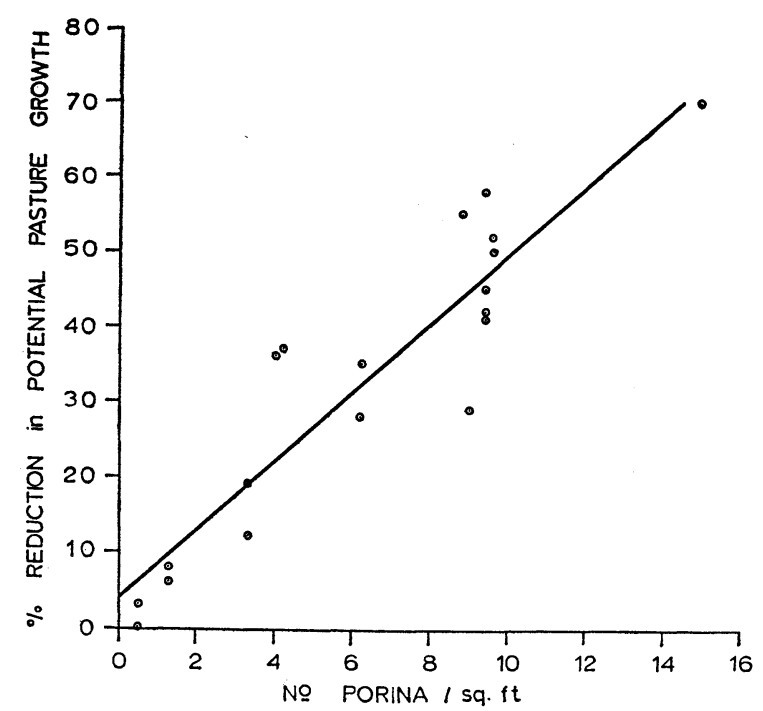

Fig. 1: Percentage reduction in potential pasture growth versus porina numbers. 
ship between pasture damage and porina numbers must be relatively constant over a variety of situations, particularly over the period April to October. If this is correct, then the amount of pasture eaten by a particular porina population appears to depend on the potential pasture growth of the site. According to the relationship shown in Fig. 1, a population of 10 porina per sq. ft for example, will eat approximately $50 \%$ of the total pasture production, whether that be 3,000 or $9,000 \mathrm{lb}$ DM per acre per annum. This implies that the amount of pasture eaten by porina varies in the same way as pasture growth, and that the environment controls the activity of porina either directly, or indirectly, by its effect on pasture growth.

There is limited field evidence that porina are controlled in the same way as pasture growth in that larvae found in relatively low-producing way an smaller than those found in areas such as parts of Central Otago are much smaller than those found in higher-producing parts of West and South
is required to substantiate this suggestion.

The Effect of Porina on Pasture Production at Different Times of the Year

There is only limited information on the extent of pasture damage caused by porina, at different times of the year. However, some of the results used in the present study indicate that the amount of damage produced depends on the stage of insect present, as well as their population numbers.

Although the pupae (present during September and October) are unable to feed, the effect of the larvae which fed during the winter appears to to feed, the effect of the larvae and affect pasture growth at the time when the insect is in the pupal instar. The carry-over cffect appears to have ceased by the time the adult stage has been reached as is demonstrated by the results obtained by F. C. Allen (unpubl.) at Lincoln College (Table 2).

TABLE 2: PASTURE GROWTH DURING SPRING AND EARLY

\begin{tabular}{|c|c|c|c|c|}
\hline \multirow[b]{2}{*}{ Treated } & \multirow[b]{2}{*}{ Harvested } & \multicolumn{2}{|c|}{$\begin{array}{l}\text { Pasture Production } \\
\text { (lb DM/acre) }\end{array}$} & \multirow{2}{*}{$\begin{array}{c}\% \text { Reduction in } \\
\text { Measured } \\
\text { Potential Growth }\end{array}$} \\
\hline & & Treated & Untreated & \\
\hline \multirow[t]{4}{*}{$20 / 4 / 67$} & $12 / 9 / 67$ & 780 & 290 & 63 \\
\hline & $25 / 9 / 67$ & 1490 & 870 & 42 \\
\hline & $25 / 10 / 67$ & 490 & 350 & 29 \\
\hline & $4 / 12 / 67$ & 750 & 740 & 1 \\
\hline \multirow[t]{4}{*}{$15 / 5 / 67$} & $12 / 9 / 67$ & 740 & 290 & 61 \\
\hline & 25/9/67 & 1510 & 870 & 42 \\
\hline & $25 / 10 / 67$ & 530 & 350 & 34 \\
\hline & $4 / 12 / 67$ & 790 & 740 & 6 \\
\hline
\end{tabular}

Damage probably commences during the summer months, although it appears that the earliest instars, living on top of the soil, eat very little live plant material (B. P. J. Molloy, pers. comm.). This means that there are plant material (B. P. months of the year (November-January) during which the insect has little effect on pasture growth. Damage probably commences in February, with the later instars, and can be considerable 
TABLE 3: PASTURE GROWTH AT ROXBURGH, 1968

\begin{tabular}{|c|c|c|c|c|}
\hline \multirow[b]{2}{*}{ Harvested } & & \multicolumn{2}{|c|}{$\begin{array}{l}\text { Pasture Production } \\
\text { (lb DM/acre) }\end{array}$} & \multirow{2}{*}{$\begin{array}{c}\% \text { Reduction in } \\
\text { Measured } \\
\text { Potential Growth }\end{array}$} \\
\hline & & Treated & Untreated & \\
\hline \multirow[t]{2}{*}{$31 / 5 / 68$} & Unfertilized & 2190 & 1700 & 22 \\
\hline & Fertilized & 2270 & 1780 & 22 \\
\hline \multirow[t]{2}{*}{$22 / 11 / 68$} & Unfertilized & 1830 & 1570 & 14 \\
\hline & Fertilized & 2080 & 2060 & 1 \\
\hline
\end{tabular}

prior to winter. Table 3 shows the effect of porina on pasture yield at the Roxburgh site.

For the purposes of advisory work, however, these losses earlier in the season are of little importance because a farmer is unlikely to consider treating his pasture until the larvae (and some damage) are visible. This means that, if the insecticide is applied in late autumn, its response is limited to the winter and spring growth. It is important to note that most of the trial results, on which the econcmic model has been based, are concerned with the porina numbers found in March, April or May, and pasture growth from the time of treatment in autumn until October or November Standardization of the time of sampling is necessary owing to the rapid change in population numbers which takes place between December and April, approximately (McLaren, in press.) This timing of sampling and treatment is in agreement with current recommendations that farmers sample their feddocks about March or April, before deciding whether or not to use organophosphate insecticides.

\section{PART II: ECONOMIC ASPECTS}

\section{Definition of the Problem}

Unlike the grass grub population, the porina population does not follow a regular cyciical growth pattern. The level of porina infestation in any one year is not directly dependent on the level of infestation in previous years. Because porina do not have a regular population growth pattern, there is no reason to consider the optimum frequency of insecticide treatments over time.

The decision which confronts the farmer or adviser is the decision to treat, or not to treat a pasture with insecticide. Because of the irregular occurrence of porina over time, the population in any one year can be considered in isolation from the population in future years. In these circumstances, the appropriate problem for economic analysis is to determine the economic threshold level of porina infestation.

The term "economic" when used in the above context, means "worth while". The "threshold level" is the lowest level. The lowest level of porina infestation at which it is worth while applying insecticide is when the cost of insecticide is equal to the benefit resulting from the use of insectcide.

The objective of this study is to determine the level of porina infestation at which the cost of insecticide is equal to the value of using insecticide. If insecticide is applied when porina numbers are equal to or greater than the above level of infestation, then maximum returns to land are obtained. For porina and other insects which have no regular infestation 
cycle, the threshold level of application also corresponds with the most profitable policy of treatment.

\section{The Cost of Insecticides}

The retail prices of the insecticides currently recommended for porina control and their cost of application are shown in Table 4. For the sake of comparison, these costs have been calculated at the $1 \mathrm{lb}$ a.i. per acre rate of application. Not only is this the recommended rate for all three chemicals concerned, but it is the rate which was selected from the results for the purposes of this analysis. However, if conditions are suitable for the use of lower rates of application, the cost per acre figure being used could be reduced accordingly. Another cost which should be included in the analysis is the opportunity cost of the capital used for purchase of insecticide and its application. The opportunity cost of capital is the return which can be obtained from investing capital in the best alternative investment available to the farmer.

In agriculture there is usually no clear distinction between working capital and capital used for investment. One of the alternative uses for capital may be the purchase of livestock. The marginal return on capital invested in livestock may be $80 \%$. In the above example, the cost of insecticide for analytical purposes is the cost landed on the farm, plus application cost, plus the opportunity cost of $80 \%$ on the capital involved in the purchase and application of insecticide.

In the majority of farm situations, the opportunity cost is the cost of borrowing working capital from the stock firm or bank at $6 \%$. The appropriate opportunity cost for an individual farm should be added to the cost in Table 4

TABLE 4: COST OF INSECTICIDES AS AT MARCH, 1969

\begin{tabular}{|c|c|c|c|c|}
\hline \multirow[b]{2}{*}{ Chemical } & & & \multicolumn{2}{|c|}{$\begin{array}{c}\text { Cost of Treatment, including Application } \\
\text { Cost, for } 1 \mathrm{lb} \text { a.i. per acre }\end{array}$} \\
\hline & & & Land & Air \\
\hline \multicolumn{5}{|l|}{ diazinon } \\
\hline Emulsion & .... & $\ldots$ & $\$ 4.14$ & $\$ 5.93$ \\
\hline Granules & $\ldots$ & $\ldots$ & $\$ 5.10$ & $\$ 4.90$ \\
\hline \multicolumn{5}{|l|}{ fenitrothion } \\
\hline Emulsion & .... & .... & $\$ 3.79-\$ 4.23$ & $\$ 5.49-\$ 6.04$ \\
\hline Prills $\quad \ldots$ & .... & .... & $\$ 3.90$ & $\$ 3.70$ \\
\hline trichlorfon & & & & $\$ 397 \$ 443$ \\
\hline Spray $\quad$.... & .... & .... & $\$ 2.58-\$ 2.94$ & $\$ 3.97-\$ 4.43$ \\
\hline
\end{tabular}

Rate of application of spray formulations applied aerially $=1.25 \mathrm{lb}$ a.i./ acre.

Application costs per acre (contractors' charges):

\begin{tabular}{|c|c|c|c|c|c|c|}
\hline Land & & & & & & \\
\hline Spray $\quad \ldots . \quad \ldots$ & $\cdots$ & .... & .... & $\cdots$ & .... & $\$ 1.00$ \\
\hline Granules or prills .... & $\ldots$ & $\ldots$. & .... & $\ldots$ & $\ldots$ & \\
\hline Aerial & & & & & & \\
\hline Spray $\quad \ldots . \quad \ldots$ & .... & $\ldots$. & .... & $\cdots$ & .... & $\$ 2.00$ \\
\hline Granules or prills .... & $\ldots$. & $\ldots .$. & .... & $\ldots$ & $\ldots$. & $\$ 0.50$ \\
\hline
\end{tabular}




\section{THE VALUE OF PASTURE DESTROYED BY PORINA}

Because the effect of insecticide is to reduce pasture damage, the value, or benefit, of using insecticide depends on the value of the pasture which would be destroyed by porina. The value of using insecticide is, therefore, the value of pasture saved. For the purpose of this discussion, it is assumed that the objective of a farmer is maximum net profit per acre from the production of meat and wool. The presence of porina conflicts with the farmers' objective because pasture production is reduced and less stock can be carried, hence net income is reduced.

The loss in carrying capacity and net income can be measured in terms of the gross margin per ewe equivalent (EE). The gross margin/EE is the gross revenue/EE less direct costs. Costs other than direct costs/EE can be regarded as fixed because they must be paid irrespective of reduced stocking rate. For the purposes of this analysis, fixed costs need not be considered. Calculations showing the derivation of a gross margin are illustrated in Appendix 1.

The value of a pasture depends only on the stocking rate, and the gross margin/EE. For example, if the gross margin/EE is $\$ 5$ and the stocking rate of a pasture is $3 \mathrm{EE}$, then the value of this pasture utilized for animal production is $3 \times \$ 5=\$ 15$. The stocking rate and the gross margin per ewe equivalent are financial measures of a pasture's production. The dry matter production of a pasture is a physical measure of a pasture's production. An economic analysis demands the use of financial measures rather than physical measures.

Allen (1968) and Rastrick and Upritchard (1968), have used a different method of valuing pasture. These writers have assessed the dry matter production of a pasture and used a constant conversion factor to determine a theoretical stocking rate. The theoretical stocking rate with appropriate financial data was then used to measure the value of a pasture. The problem with this approach is that on different farms there is not a constant relationship between dry matter production and stocking rate. The above method of pasture valuation takes no account of pasture utilization in different environments and under different management.

The relationship between porina larvae numbers and percentage of pasture destroyed has been discussed. Using this relationship, the value of pasture damage caused by porina can be calculated (Table 5). One of the necessary assumptions is that the amount by which the net revenue from a pasture decreases as a result of porina destruction is directly proportional to, and is a linear function of, the amount of dry matter destroyed.

TABLE 5: POTENTIAL VALUE OF PASTURE DESTROYED VERSUS PORINA NUMBERS

\begin{tabular}{|c|c|c|c|c|c|c|}
\hline \multirow{3}{*}{$\begin{array}{c}\text { Porina No./ } \\
\text { sq. } f t\end{array}$} & \multirow{3}{*}{$\begin{array}{c}\% D M \\
\text { Destroyed }\end{array}$} & \multirow{3}{*}{1} & \multicolumn{4}{|c|}{ Stocking Rate in EE } \\
\hline & & & 2 & 4 & 6 & 8 \\
\hline & & & \multicolumn{4}{|c|}{${ }^{*}$ Value of Pasture Destruction } \\
\hline 2 & 13.78 & 0.67 & 1.38 & 2.76 & 4.58 & 5.52 \\
\hline 4 & 23.02 & 1.15 & 2.30 & 4.60 & 7.68 & 9.20 \\
\hline 8 & 36.96 & 1.85 & 3.70 & 7.40 & 12.3 & 14.80 \\
\hline 12 & 55.44 & 2.77 & 5.54 & 11.08 & 18.4 & 22.16 \\
\hline
\end{tabular}

*The gross margin/ewe equivalent $=\$ 5.00$. 


\section{ECONOMIC MODEL}

An economic model is a theoretical solution to a problem and provides a mental picture of the relationships involved. The problem is to determine the level of porina infestation at which the value of insecticide is equal to the cost of applying insectioide. One of the functions of a model is to describe the conditions which must hold for achieving a solution to the problem.

The model which will be described provides a solution to the problem when a number of conditions and simplifying assumptions are made. The conditions and assumptions are listed and discussed below:

(1) The relationship between porina caterpillar numbers and the proportion of pasture dry matter destroyed is considered over the period April to October.

(2) The period of the year when the feed supply on farms is most limited occurs between April and Octcber. Most farms which are predominantly livestock farms do, in fact, conform with the above condition.

(3) The proportion of pasture destroyed at any point in time during the period October to April is the same as for the whole period. At present there is no evidence that this assumption is correct. If the assumption is not correct, then the model is providing only an approximate solution.

(4) Treatment is a fixed input per acre and one application of insecticide gives complete control of all porina.

(5) Farms are fully stocked under their present management systems. This condition does not imply that a farm must be stocked to its potential carrying capacity. For example, two farms in a similar environment may have very different stocking rates. However, both farms may be fully stocked under the management system to which they are subjected.

(6) At the time that a decision is made to apply insecticide, all costs and prices are known with certainty

(7) The proportion of pasture destroyed depends only on porina numbers.

(8) Stocking rate is formulated independent of porina. The farmer or adviser decides on the stocking rate as if porina did not exist.

(9) The decline in per acre value of meat and wool production as a result of porina infestation is directly proportional to and is a linear function of the decline in dry matter production.

Provided the above nine conditions are fulfilled, the following model is appropriate for determining economic threshold levels for insecticide use.

Where $S=$ Stocking rate EE/acre

$C=$ Cost of insecticide/acre

$P=$ Pasture production

$Z=$ Gross margin/ewe equivalent

$X=$ Porina larvae numbers

$Y=\%$ Pasture destroyed by porina

and given that $Y=4.62 X+4.54$ 
The value of pasture production $P=S Z$

The proportion of pasture required to equate treatment cost $C=C / S Z$ $\times 100 / 1=Y$.

The relationship $Y=4.62 X+4.54$ is used determine the number of porina which will destroy $Y \%$ of pasture dry matter.

$X=(Y-4.54) / 4.62$

$X=$ Economic threshold number of porina to equate treatment cost $C$.

Example

Cost of treatment $=\$ 3.45$

Stocking rate/acre $=4 \mathrm{EE}$

Gross margin $/ \mathrm{EE}=\$ 5$

The percentage of pasture required to equate treatment cost

$$
\begin{aligned}
& =C / S Z \times 100 / 1 \\
& =\$ 3.45 / \$ 20 \times 100 / 1 \\
& =17.2 \% \\
\mathrm{X} & =(17.2-4.54) / 4.62 \\
& =2.67 \text { porina/sq. } \mathrm{ft} \\
& =\text { Economic threshold }
\end{aligned}
$$

Graphical Illustration of Model

The model has been illustrated graphically in Fig. 2. Cost of insecticide lines are superimposed on a graph which illustrates the value of pasture destroyed by different levels of porina infestation, at selected stocking rates. The economic threshold is that number of porina larvae at the intersection of the iso cost and iso stocking rate lines.

An alternative presentation is provided in Fig. 3 where the economic threshold is represented by a rectangular hyperbola. Any point on the curve indicates the number of porina at the indicated stocking rate which will destroy a quantity of pasture equal in value to the selected cost of insecticide.

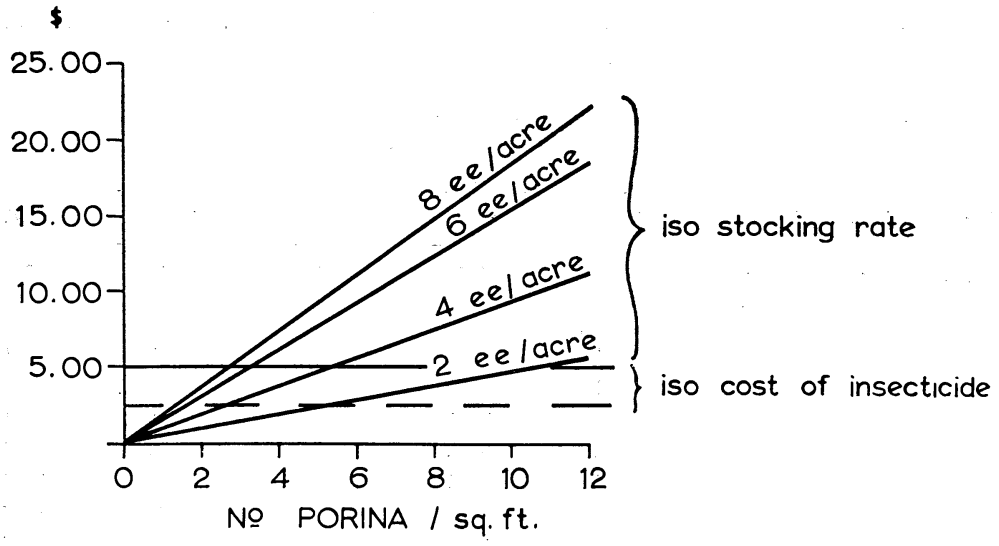

FIG. 2: Value of pasture destroyed versus porina numbers.

(Costs of insecticide $\$ 2.50$ and $\$ 5.00$. Gross margin/EE $\$ 5.00$ ) 


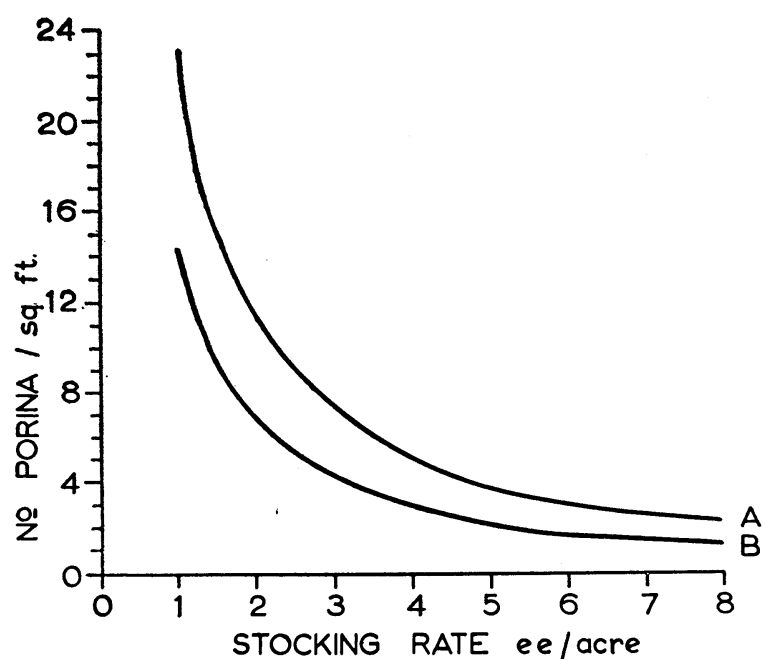

Fig. 3: The economic threshold at varying stocking rates and selected costs of insecticide.

( $A=$ insecticide cost of $\$ 5.00 . B=$ insecticide cost of $\$ 3.50$. Gross margin/ EE \$5.00)

\section{Economic Threshold Tables}

Differences in the number of porina which represent the economic threshold are caused by variation in three of the parameters used in the model. The parameters are:

(1) Stocking rate.

(2) Cost of insecticide.

(3) Gross margin/ewe equivalent.

Tables 6 to 13 present the economic threshold number of porina per sq. $\mathrm{ft}$ for a wide range in the above parameters.

TABLE 6: 1 EWE EQUIVALENT TO THE ACRE - COST OF INSECTICIDE (\$)

\begin{tabular}{rccccc}
\hline Gross Margin EE & 4.00 & 4.50 & 5.00 & 5.50 & 6.00 \\
\hline Total Gross Margin & 4 & 4.5 & 5 & 5.5 & 6 \\
1 Acre & & & & & \\
\hline 2.50 & 12.55 & 11.04 & 9.84 & 8.85 & 8.04 \\
3.00 & 15.25 & 13.45 & 12.00 & 10.82 & 9.84 \\
3.50 & 17.96 & 15.85 & 14.17 & 12.79 & 11.64 \\
4.00 & 20.66 & 18.26 & 16.33 & 14.76 & 13.45 \\
4.50 & 23.26 & 20.66 & 18.50 & 16.73 & 15.25 \\
5.00 & 26.07 & 23.07 & 20.66 & 18.69 & 17.05 \\
5.50 & 28.78 & 25.47 & 22.83 & 20.66 & 18.86 \\
6.00 & 31.48 & 27.88 & 24.99 & 22.63 & 20.66 \\
\hline
\end{tabular}


TABLE 7: 2 EWE EQUIVALENTS TO THE ACRE - COST OF INSECTICIDES (\$)

\begin{tabular}{rrrrrr}
\hline Gross Margin EE & 4.00 & 4.50 & 5.00 & 5.50 & 6.00 \\
\hline Total Gross Margin & 8 & 9 & 10 & 11 & 12 \\
1 Acre & & & & & \\
\hline 2.50 & 5.78 & 5.05 & 4.43 & 3.94 & 3.53 \\
3.00 & 7.13 & 6.23 & 5.51 & 4.92 & 4.43 \\
3.50 & 8.49 & 7.44 & 6.59 & 5.90 & 5.33 \\
4.00 & 9.84 & 8.64 & 7.68 & 6.89 & 6.23 \\
4.50 & 11.19 & 9.84 & 8.76 & 7.87 & 7.13 \\
5.00 & 12.55 & 11.04 & 9.84 & 8.85 & 8.04 \\
5.50 & 13.90 & 12.24 & 10.92 & 9.84 & 8.94 \\
6.00 & 15.25 & 13.45 & 12.00 & 10.82 & 9.84 \\
\hline
\end{tabular}

TABLE 8 : $\ddot{\jmath}$ EWE EQUIVALENTS TO THE ACRE - COST OF INSECTICIDES (\$)

\begin{tabular}{rrrrrc}
\hline Gross Margin EE & 4.00 & 4.50 & 5.00 & 5.50 & 6.00 \\
\hline Total Gross Margin & 12 & 13.5 & 15 & 16.5 & 18 \\
1 Acre & & & & & \\
\hline 2.50 & 3.53 & 3.03 & 2.63 & 2.30 & 2.02 \\
3.00 & 4.43 & 3.83 & 3.35 & 2.95 & 2.63 \\
3.50 & 5.33 & 4.63 & 4.07 & 3.61 & 3.23 \\
4.00 & 6.23 & 5.43 & 4.79 & 4.26 & 3.83 \\
4.50 & 7.13 & 6.23 & 5.51 & 4.92 & 4.43 \\
5.00 & 8.04 & 7.03 & 6.23 & 5.58 & 5.03 \\
5.50 & 8.94 & 7.84 & 6.95 & 6.23 & 5.63 \\
6.00 & 9.84 & 8.64 & 7.68 & 6.89 & 6.23 \\
\hline
\end{tabular}

TABLE 9: 4 EWE EQUIVALENTS TO THE ACRE - COST OF INSECTICIDES (\$)

\begin{tabular}{rccccc}
\hline Gross Margin EE & 4.00 & 4.50 & 5.00 & 5.50 & 6.00 \\
\hline Total Gross Margin & 16 & 18 & 20 & 22 & 24 \\
1 Acre & & & & & \\
\hline 2.50 & 2.40 & 2.02 & 1.72 & 1.48 & 1.27 \\
3.00 & 3.08 & 2.63 & 2.26 & 1.97 & 1.72 \\
3.50 & 3.75 & 3.23 & 2.81 & 2.46 & 2.17 \\
4.00 & 4.43 & 3.83 & 3.35 & 2.95 & 2.63 \\
4.50 & 5.11 & 4.43 & 3.89 & 3.44 & 3.08 \\
5.00 & 5.78 & 5.03 & 4.43 & 3.94 & 3.53 \\
5.50 & 6.46 & 5.63 & 4.97 & 4.43 & 3.98 \\
6.00 & 7.13 & 6.23 & 5.51 & 4.92 & 4.43 \\
\hline
\end{tabular}

31? 
TABLE 10: 5 EWE EQUIVALENTS TO THE ACRE - COST OF INSECTICIDES (\$)

\begin{tabular}{rccccc}
\hline Gross Margin EE & 4.00 & 4.50 & 5.00 & 5.50 & 6.00 \\
\hline Total Gross Margin & 20 & 22.5 & 25 & 27.5 & 30 \\
1 Acre & & & & & \\
\hline 2.50 & 1.72 & 1.42 & 1.18 & 0.98 & 0.82 \\
3.00 & 2.26 & 1.90 & 1.61 & 1.38 & 1.18 \\
3.50 & 2.80 & 2.39 & 2.05 & 1.77 & 1.54 \\
4.00 & 3.35 & 2.87 & 2.48 & 2.17 & 1.90 \\
4.50 & 3.89 & 3.35 & 2.91 & 2.56 & 2.26 \\
5.00 & 4.43 & 3.83 & 3.35 & 2.95 & 2.63 \\
5.50 & 4.97 & 4.31 & 3.78 & 3.35 & 2.98 \\
6.00 & 5.51 & 4.79 & 4.21 & 3.74 & 3.35 \\
\hline
\end{tabular}

TABLE 11: 6 EWE EQUIVALENTS TO THE ACRE - COST OF INSECTICIDES (\$)

\begin{tabular}{rccccc}
\hline Gross Margin EE & 4.00 & 4.50 & 5.00 & 5.50 & 6.00 \\
\hline Total Gross Margin & 27 & 27 & 30 & 33 & 36 \\
1 Acre & & & & & \\
\hline 2.50 & 1.27 & 1.02 & 0.82 & 0.66 & 0.52 \\
3.00 & 1.72 & 1.42 & 1.18 & 0.98 & 0.82 \\
3.50 & 2.17 & 1.82 & 1.54 & 1.31 & 1.12 \\
4.00 & 2.63 & 2.22 & 1.90 & 1.64 & 1.42 \\
4.50 & 3.08 & 2.63 & 2.26 & 1.97 & 1.72 \\
5.00 & 3.53 & 2.63 & 2.30 & 2.30 & 2.02 \\
5.50 & 3.98 & 3.43 & 2.98 & 2.63 & 2.32 \\
6.00 & 4.45 & 3.83 & 3.35 & 2.95 & 2.63 \\
\hline
\end{tabular}

TABLE 12: 7 EWE EQUIVALENTS TO THE ACRE - COST OF INSECTICIDES (\$)

\begin{tabular}{rccccc}
\hline Gross Margin EE & 4.00 & 4.50 & 5.00 & 5.50 & 6.00 \\
\hline Total Gross Margin & 28 & 31.5 & 35 & 38.5 & 42 \\
1 Acre & & & & & \\
\hline 2.50 & 0.95 & 0.74 & 0.56 & 0.42 & 0.31 \\
3.00 & 1.34 & 1.08 & 0.87 & 0.70 & 0.56 \\
3.50 & 1.72 & 1.42 & 1.18 & 0.98 & 0.82 \\
4.00 & 2.11 & 1.77 & 1.49 & 1.27 & 1.08 \\
4.50 & 2.49 & 2.11 & 1.80 & 1.55 & 1.34 \\
5.00 & 2.88 & 2.45 & 2.11 & 1.83 & 1.59 \\
5.50 & 3.27 & 2.80 & 2.42 & 2.11 & 1.85 \\
6.00 & 3.66 & 3.14 & 2.73 & 2.39 & 2.11 \\
\hline
\end{tabular}


TABLE 13: 8 EWE EQUIVALENTS TO THE ACRE - COST OF INSECTICIDES (\$)

\begin{tabular}{|c|c|c|c|c|c|c|}
\hline & 4.00 & 4.50 & 5.00 & 5.50 & 6.00 \\
\hline \multicolumn{2}{|c|}{ 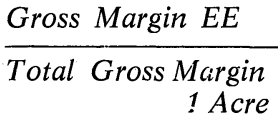 } & 32 & 36 & 40 & 44 & 48 \\
\hline & 2.50 & 0.71 & 0.52 & 0.37 & 0.25 & 0.14 \\
\hline & 3.00 & 1.05 & 0.82 & 0.64 & 0.49 & 0.37 \\
\hline & 3.50 & 1.39 & 1.12 & 0.91 & 0.74 & 0.60 \\
\hline & 4.00 & 1.72 & 1.42 & 1.18 & 0.98 & 0.82 \\
\hline & 4.50 & 2.06 & 1.72 & 1.45 & 1.23 & 1.05 \\
\hline & 5.00 & 2.40 & 2.02 & 1.72 & 1.48 & 1.27 \\
\hline & 5.50 & 2.74 & 2.32 & 1.99 & 1.72 & 1.50 \\
\hline & 6.00 & 3.09 & 2.63 & 2.26 & 1.97 & 1.72 \\
\hline
\end{tabular}

\section{AN Appraisal}

The prescriptive value of an economic model depends on its ease of application and the reality or applicability of the results obtained. This section discusses from the farmer or adviser's point of view the ease or difficulty of determining the economic threshold and the value of the economic threshold as a means of deciding when it is worth while to treat a pasture for porina control.

The method of sampling a pasture to determine the extent and severity of porina infestation is a separate issue and will not be discussed. Having determined the level of porina infestation, the farmer would refer to the tables to determine whether or not the infestation is above or below the economic threshold level. At the time the decision to apply, or not to apply, insecticide is being made, the stocking rate and the cost of the insecticide are known with certainty. The only variable is the gross margin/ewe

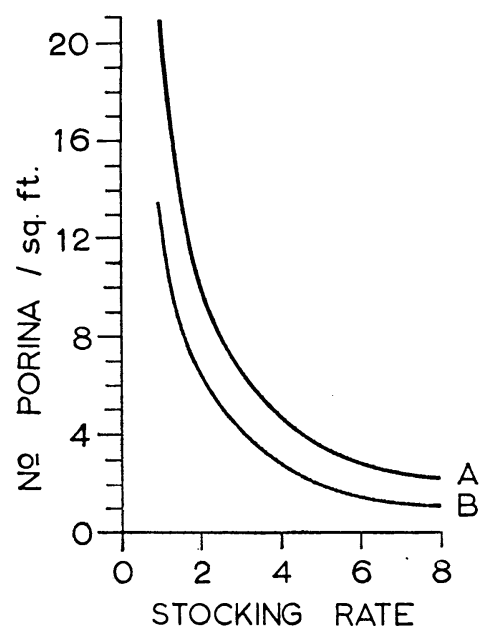

FIg. 4: The effect of a $\$ 2$ variation in gross margin

( $A=$ gross margin of $\$ 4.00$. $B=$ gross margin of $\$ 6.00$. Cost of insicin.tue $\$ 4.00)$ 
equivalent. A precise solution is, therefore, possible. The farmer will be able to make some probability estimate of the gross margin/EE. The effect of a $\$ 2.00$ variation in gross margin/EE is illustrated in Fig. 4.

There are several problems associated with porina infestation which have not been included in the model and which should be considered. These problems are:

(1) The possibility of permanent pasture destruction.

(2) The increase of weeds in the pasture.

(3) Increased need for winter feed.

The following discussion will show that the threshold levels obtained by using the model are compatible with having included the above problems in the model.

Permanent pasture destruction is only likely at relatively high porina numbers. Consultation with the graphs and tables indicates that, under a low stocking rate, permanent pasture damage is a possibility because the model prescribes treatment when porina numbers are relatively high. However, under a low stocking rate either (a) the level of utilization is very low, or (b) the pasture is a very low producing pasture.

(a) If utilization is low, then a permanent deterioration in the pasture is not likely to result in a lower stocking rate. Hence net profit from the sale of meat and wool will not be reduced. Furthermore, where utilization is low, the pasture is likely to deteriorate, irrespective of the presence or absence of porina.

(b) If the pasture is low producing, the presence of porina will not cause a permanent loss of production because, whatever takes the place of the present species, is likely to provide an equally satisfactory pasture.

The increase of weeds in a pasture is one form of pasture deterioration which can result from the activities of porina. Weed ingression will occur when a relatively high proportion of the pasture is destroyed. In Southland, daisy (Bellis perennis) is frequently found in pastures which have suffered porina attack. The same logic applies to weed ingression as that which applies to pasture destruction in general. Where weed ingression as a result of porina damage will result in lower meat and wool production per acre, the model will prescribe treatment of the pasture for porina control.

The destruction of pasture by porina results in a shortage of winter or spring fee:3. For animal production to remain constant when pastures are attacked by porina, there must be an increase in the supply of winter feed and supplementary feed. The value of applying insecticide could have been assessed on the basis of the amount of winter feed saved. This approach has not been used because the production or saving of winter feed is not generally a farming objective. The usual farming objective is maximum net profit/acre from the production of meat and wool. The use of insecticide has been justified according to the above objective. The use or non-use of winter feed must be justified according to the same criterion.

For winter feeding to be profitable, the marginal cost of winter feed must be equal to or less than the marginal revenue in terms of meat and wool production. The provision of winter feed and the application of insecticide are separate issues. When making decisions to maximize profit, each issue should be analysed independently in terms of the overall farming objective. 


\section{Weaknesses of Present Study}

(1) None of the results used were collected from grazed trials. The nature of the interaction between stock, porina and pasture growth at different times of the year has not been considered owing to the absence of information on the subject, but it is recognized that such information should ideally have been known before such a model was formulated.

(2) Condition (3) states that: The proportion of pasture destroyed at any point in time during the period April to October, is the same as the proportion for the whole period. This assumption is probably not
correct.

If there were no flexibility between feed supply and feed demand within the period April to October, the nonconformity of porina damage with the above assumption would be important. In practice, however, there is flexibility of feed supply between weeks or even months. The model will therefore provide a realistic solution, provided that the flexibility in feed supply is sufficient to counteract the difference in proportion of pasture destroyed at different times. A more realistic model could be formulated if the proportion of pasture destroyed at any point in time between April and October was known.

(3) Condition (9) states that: The value of meat and wool production is directly proportional to, and is a linear function of, the amount of dry matter utilized. This assumption is not correct. In practice, the value of meat and wool production is a decreasing function of the amount of dry matter utilized. Each additional unit of dry matter utilized results in a smaller increase in product than the preceding unit. If knowledge of the production function between dry matter and meat and wool production were available, the real relationship could be used in the model. In the absence of this information, a linear relationship has been used. The writers do not consider that the linear approximation used in the model seriously impairs the prescriptive value of the model.

Because of the above three weaknesses, the model may not always provide an accurate economic threshold. The above weaknesses could provide reasons for treating certain parts of a farm with insecticide, when porina numbers differ from the economic threshold level. However, the writers consider that the model provides the best available guide to the profitable application of insecticide for porina control.

\section{ACKNOWLEDGEMENTS}

Thanks are due to Mrs J. Pearson for her help with the field work in Central Otago, to G. Thorley and others for their assistance in the mowing of the trials, and to the chemical companies who offered trial results as well as assistance in the collection of information necessary for the study. We would like to thank F. C. Allen for making available the results of his trials, the majority of which had not been published previously. Discussions during the preparation of this paper with F. C. Allen, M. A. Monteath, G. Donovan and L. T. Evans were also much appreciated. 


\section{REFERENCES}

Allen, F. C., 1968: Proc. 21st N.Z. Weed \& Pest Control Conf.: 198-201. Cassels, G. R., 1966: Proc. 19th N.Z. Weed \& Pest Control Conf.: 230-5. Flay, A. H.; Garrett, J., 1942: N.Z. J. Sci.Tech., 23.

Fensed \& Pest Control Conf.: 135-49.

Rastrick, D. R.; Upritchard, E. A., 1968: Proc. 21st N.Z. Weed \& Pest Control Conf.: 192-7.

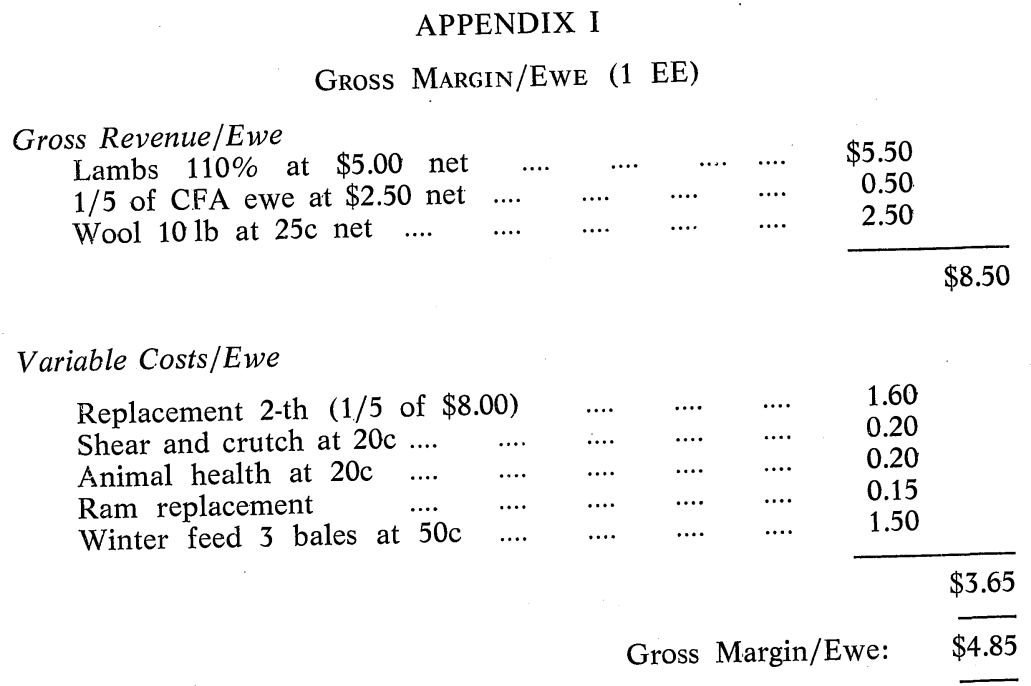

